\title{
IDENTIFICATION OF NON PLASTIDIC ADP-GLUCOSE PYROPHOSPHORYLASE UNCONVENTIONAL PARTNERS IN Arabidopsis thaliana
}

\author{
Pham Ngoc Vinh ${ }^{1}$ *, Hong Gil Nam ${ }^{1}$, Nguyen Huy Hoang ${ }^{2}$ \\ ${ }^{1}$ Pohang University of Science and Technology, South Korea, *phamngocvinh1988@gmail.com \\ ${ }^{2}$ Institute of Genome Research (IGR), Vietnam Academy of Science and Technology
}

\begin{abstract}
ADP-glucose pyrophosphorylase (ATP: alpha-glucose-1-phosphate adenylyl transferase, ADGase) previously has been studied as a key regulatory enzyme in the starch biosynthetic pathway in plant. Surprisingly, ADP-glucose pyrophosphorylase small subunit APS1 (ADG1) was found not only in chloroplast but also in non plastidic region, especially, small proportion in nucleus. To elucidate the novel mechanisms underlying non plastidic ADG1 actions, yeast two-hybrid screening was used to identify proteins associated with ADG1. Yeast two hybrid and co-immunoprecipitation (Co-IP) assay were used to confirm the interaction between ADG1 and interacting candidates. Furthermore, localization of interacting proteins was analyzed using Green Fluorescent Protein (GFP) fusion proteins under laser scanning microscopy. Two protein RPC4 (RNA polymerase III subunit) and LSU3 (Response to low Sulfur 3) were confirmed as strong candidates that interact with ADG1. Therefore, we hypothesized that non plastidic localized ADG1 might have additional function which mediates plant cellular metabolism status and intracellular signaling to regulate proper plant growth and development.
\end{abstract}

Keywords: Arabidopsis thaliana, ADP-glucose pyrophosphorylase, co-immunoprecipiation, GFP, yeast two hybrid.

\section{INTRODUCTION}

ADP-glucose pyrophosphorylase (ATP: aglucose-1-phosphate adenylyl transferase, ADPG pyrophosphorylase, ADGase) is a key regulatory enzyme in the starch biosynthetic pathway in plants. This enzyme catalyzes the synthesis of ADP-glucose and pyrophosphate from glucose-1-phosphate and ATP [2, 12, 15]. It was suggested that the native ADGase of plants formed as heterotetramer with two large and two small subunits. Six genes encode proteins with homology to ADP-GlcPPase, two of these genes encode for S subunits (APS1 and APS2) and four encode L subunits (APL1APL4) [13]. According to enzyme activity and mRNA expression pattern studies, it has been proposed that the only functional $\mathrm{S}$ subunit in Arabidopsis is APS1 (ADG1), while APS2 may be in a process of pseudogenization [16].

The adgl mutant has a mutation in the small subunit gene (designated as APS1), and the adg2 mutant has a mutation in the large subunit gene (designated as APL1). The starchless phenotype of the adgl mutant, which lacks
ADGase activity, suggests that ADGase produced in plastid is the substrate for starch synthesis [1112]. It has been suggested that APL1 homologs (APL2, APL3, and APL4) may also form heterotetramers with APS1 based on the presence of specific isoforms and play roles in starch metabolism in response to various metabolic states of tissues [14].

Surprisingly, in our previous data, ADG1 can be expressed and detected not only in chloroplast but also in non-plastidic region, especially small proportion in nucleus. Transient transformation assays performed with Arabidopsis suspension cell protoplasts showed that the expression of the GFP fusion ADG1 was found in $10 \%$ in nucleus. In addition, our previous data also showed evidence that endogenous ADG1 resides in non-plastidic region and in the nucleus of intact Arabidopsis plants by using specific ADG1 antibody. Previous evidences suggested another location of ADG1 chloroplast-metabolic enzyme and the investigation seeking unconventional/non catalytic functions of ADG1. Therefore, we 
Pham Ngoc Vinh, Hong Gil Nam, Nguyen Huy Hoang

hypothesized that ADG1 might have additional function, which mediates plant cellular metabolism status and intracellular signaling to regulate proper plant growth and development.

\section{MATERIALS AND METHODS}

Plant material and growth conditions
All plants were grown in an environmentally controlled growth room at $22^{\circ} \mathrm{C}$ with a $16-\mathrm{h} / 8-\mathrm{h}$ light/dark cycle. For phenotypic assays, seeds were cold-treated at $4^{\circ} \mathrm{C}$ for 3 days, sown directly in the soil transferred to white light intensity (normal light intensity) $\left(85 \mu \mathrm{mol} \cdot \mathrm{m}^{-2} \cdot \mathrm{s}^{-1}\right)$.

Table 1. Full length cDNA of ADG1 and interacting candidates

\begin{tabular}{ccc}
\hline Number & Gene name & cDNA length \\
\hline 1 & ADP-glucose pyrophosphorylase ( ADG1) & $1.563 \mathrm{~kb}$ \\
2 & RPC4 (RNA Polymerase III Subunit 4) & $819 \mathrm{bp}$ \\
3 & LSU3 (Response to low Sulfur 3) & $294 \mathrm{bp}$ \\
4 & ERF7 (Ethylene Response Factor 7) & $735 \mathrm{bp}$ \\
5 & STOP1 (Sensitive To Proton Rhizotoxicity 1) & $1.5 \mathrm{~kb}$ \\
6 & SEC14 (cytosolic factor family protein) & $1.665 \mathrm{~kb}$ \\
7 & At3g19895 ( unknown protein) & $1.665 \mathrm{~kb}$ \\
\hline
\end{tabular}

\section{Yeast two-hybrid assay}

The DupLEX-A system (OriGene Technologies, http://www.origene.com) was used for the yeast two-hybrid assay. Full-length $1.563 \mathrm{~kb}$ ADG1 and interacting candidate' cDNAs (table 1) were cloned into the gGilda bait and gJG4-5 prey vectors, which produced in-frame fusions with the LexA DNA-binding and B42 activation domain, respectively. The yeast strain EGY48 (MATa, trp1, his3, ura3, leu2::6 LexAop-LEU2) contains the lacZ reporter plasmid pSH18-34. This strain was transformed with the appropriate 'bait' and 'prey' plasmids and interactions were detected on 5-bromo-4-chloro-3-indolyl- $\beta$-D galactopyranoside (X-gal) medium. A $\beta$ galactosidase activity assay was performed on transformants, as described previously [5].

\section{In vivo co-immunoprecipitation assay}

The cDNA full-length interacting candidates (table 1) were fused to GFP encoding sequences controlled by the CsVMV promoter. Arabidopsis mesophyll protoplasts were isolated from mature leaves of the wild type plants and transfected with ADG1 tagged haemagglutinin (HA). Protoplasts were then supplemented with the proteasome inhibitor MG132 and incubated overnight at $22^{\circ} \mathrm{C}$ in the white light. Cells were harvested and solubilized in immunoprecipitation (IP) buffer
[50 $\mathrm{mM}$ 2-amino-2-hydroxymethyl-1,3propanediol (Tris-HCl) (pH 7.5), $150 \mathrm{mM}$ $\mathrm{NaCl}, 1$ mM EDTA, 0.1\% NP-40, 0.1\% SDS, 1 $\mathrm{mM}$ phenylmethylsulphonyl fluoride (PMSF), IM MG132 and protease inhibitor cocktail (Roche)]. The extracts were centrifuged at $12.000 \mathrm{rpm}$ for 15 minutes at $4^{\circ} \mathrm{C}$ and then the supernatant was incubated with $3 \mu$ l of agaroseconjugated anti-GFP monoclonal antibody (Santa Cruz Biotechnology) for $4 \mathrm{~h}$ at $4^{\circ} \mathrm{C}$, followed by re-centrifugation. The pellet fraction was washed four times with IP buffer and protein samples were separated on $10 \%$ SDS-PAGE gels, transferred to polyvinylidene fluoride (PVDF) membranes, and detected with HRP-conjugated monoclonal anti-HA (Roche) or HRP-conjugated monoclonal anti-GFP (Santa Cruz Biotechnology) antibodies.

\section{Transient expression in plant protoplasts}

Arabidopsis mesophyll protoplasts were isolated from mature leaves of the wild type plants, using enzyme solution and incubated during three to four hours. Protoplast were then transfected using PEG- transfection procedures with GFP fusion constructs for the expression of green fluorescent protein (GFP) fusion proteins in localization experiments and HA tagged constructs for the Co-IP experiments. Protoplasts were then supplemented with the MG132 (1 M) and incubated overnight at $22^{\circ} \mathrm{C}$ in the white light [17]. 
Identification of non plastidic adp-glucose pyrophosphorylase

Table 2. Putative interaction candidates of ADG1 through Yeast two hybrid screening

\begin{tabular}{|c|c|c|c|}
\hline Interacting candidates & Locus & $\begin{array}{c}\text { Predicted } \\
\text { Localization }\end{array}$ & Function \\
\hline $\begin{array}{l}\text { LSU3 (Response To } \\
\text { Low Sulfur 3) (LSU3)* }\end{array}$ & AT3G49570 & $\begin{array}{l}\text { Plastid/mitochondria/ } \\
\text { Extracellular }\end{array}$ & $\begin{array}{l}\text { Response to low sulfur } 3 \\
\text { (LSU3) }\end{array}$ \\
\hline $\begin{array}{l}\text { ERF7 (Ethylene } \\
\text { Response Factor 7) }\end{array}$ & AT3G20310 & Nucleus, chloroplast & $\begin{array}{l}\text { Transcription factor that binds } \\
\text { to the GCC-box pathogenesis- } \\
\text { related promoter element. }\end{array}$ \\
\hline $\begin{array}{l}\text { DNA-directed RNA } \\
\text { polymerase III RPC4 } \\
\text { family protein (RPC4) }\end{array}$ & AT5G09380 & $\begin{array}{l}\text { Nucleus }(70 \%) \\
\text { chloroplast, cytosol }\end{array}$ & $\begin{array}{l}\text { DNA-directed RNA } \\
\text { polymerase III subunit RPC4 }\end{array}$ \\
\hline $\begin{array}{l}\text { DNAJ heat shock N- } \\
\text { terminal domain- } \\
\text { containing protein }\end{array}$ & AT2G25560 & $\begin{array}{l}\text { Cytosol, nucleus, } \\
\text { chloropast }\end{array}$ & heat shock protein binding \\
\hline $\begin{array}{l}\text { STOP1 (sensitive to } \\
\text { proton rhizotoxicity 1) }\end{array}$ & AT1G34370 & Nucleus, cytosol & $\begin{array}{l}\text { Probable transcription factor. } \\
\text { tolerance to major stress } \\
\text { factors in acid soils }\end{array}$ \\
\hline $\begin{array}{l}\text { Unknown protein } \\
\text { (AT3G19895) }\end{array}$ & AT3G19895 & $\begin{array}{l}\text { Plastid/nucleus } \\
\text { (Chloroplast major) }\end{array}$ & Unknown function \\
\hline $\begin{array}{l}\text { SEC14 cytosolic factor } \\
\text { family protein }\end{array}$ & AT1G72160 & cytosol, nucleus & $\begin{array}{l}\text { Sec14p-like } \\
\text { phosphatidylinositol transfer }\end{array}$ \\
\hline
\end{tabular}

\section{RESULTS AND DISCUSSION}

\section{Identification of non plastidic ADG1 Unconventional Partners}

To elucidate the novel mechanisms underlying the non plastidic ADG1 actions, yeast two-hybrid screening was used to identify proteins associated with ADG1. Yeast two hybrid screening of ADG1 bait was performed in yeast containing three reporters (URA3, lacZ and ADE2). 17 yeast colonies were identified that expressed three reporter genes encoded for seven Arabidopsis protein candidates (table 2). LSU3 is still unknown function in Arabidopsis. However, in A. thaliana homolog genes, named LSU1-LSU4 (Response to low sulfur), two of them were reported strongly up-regulated by Sdeficit. Moreover, homologs of LSU3, UP9C gene and the UP9-like family in tobacco, which were reported as novel regulators of Plant Response to Sulfur Deficiency.

APETALA2/EREBP-type transcription factor, AtERF7, has been shown to play an important role in $\mathrm{ABA}$ responses, interacting with the protein kinase PKS3 that has been shown to be a global regulator of $\mathrm{ABA}$ responses. The identification of RPC4 as one of the ADG1 interacting candidate was also surprising. RPC4 protein encoded for putative specific RNA polymerase III small subunit 4 (TAIR). RNA polymerase III (RNAP III) is a conserved 17-subunit enzyme that transcribes genes encoding short untranslated RNAs such as transfer RNAs (tRNAs) and 5S ribosomal RNA (rRNA). However, function of RPC4 in Arabidopsis development is still unknown so far.

\section{Sub-cellular localization of interacting proteins}

To determine the sub-cellular localization of interacting candidates, gateway cloning using CsVMV- eGFP-N-999 vector for the expression of green fluorescent protein (GFP) fusion proteins in plant protoplasts has been performed. Transformed protoplasts were analyzed by confocal laser scanning microscopy. Among seven candidates, RPC4 (RNA Polymerase III Subunit 4), LSU3 (Response to low Sulfur 3), ERF7 (Ethylene Response Factor 7) and STOP1 (Sensitive To Proton Rhizotoxicity 1) showed nucleus localization whereas other two, (SEC14 and 
At3g19895) localize in cytoplasm (fig. 1). Interestingly, nuclear RPC4 protein formed two different patterns, both dispersed form and speckle form in nucleus (fig. 1 and fig. 2). The cytoplasm background GFP was used as the negative control.

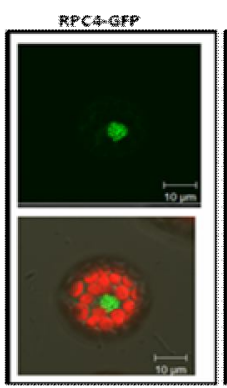

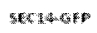

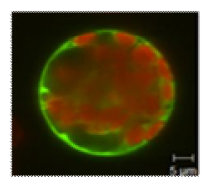

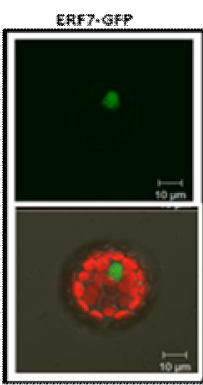

Ar

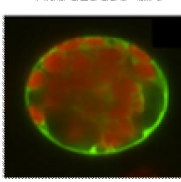

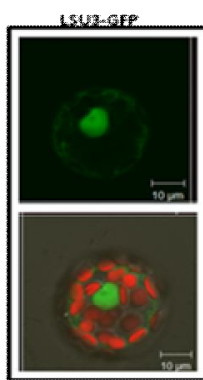

糔

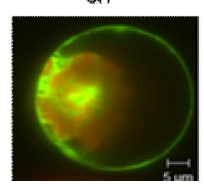

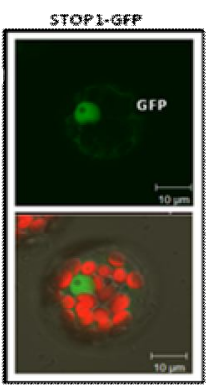

Cytoplasm localization

Figure 1. Sub-cellular localization of interacting candidates

In transient transformation assays performed with Arabidopsis suspension cell protoplasts, the expression of the GFP fusion proteins was driven by the CsVMV promoter. GFP signal that is found in both cytosol and nucleus was used as control. Scale Bar $=10 \mu \mathrm{m}$ and $5 \mu \mathrm{m}$. Auto: Autofluoresence.
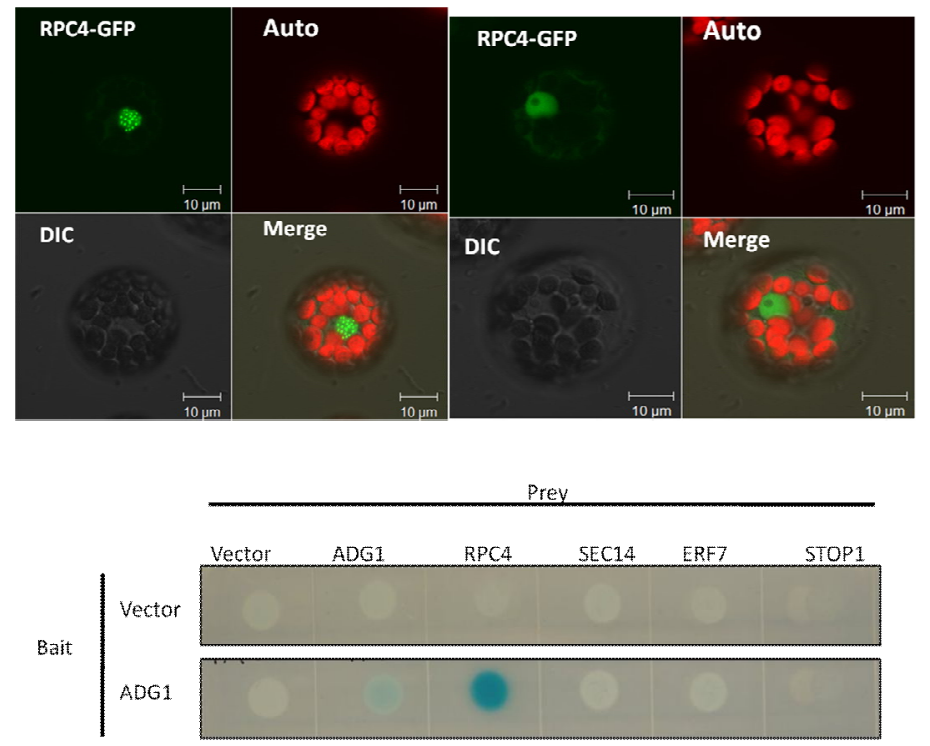

Batat

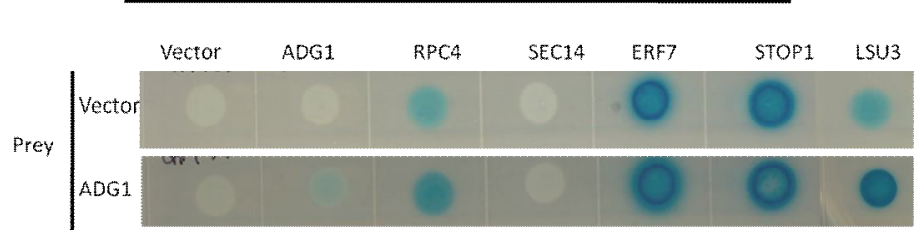

Figure 2. Nuclear RPC4 protein formed two different patterns, both dispersed form and speckle form in nucleus. Scale bar $=10$ $\mu m$.

Figure 3. Yeast two hybrid confirmation interaction between ADG1 and unconventional partners. Interaction between ADG1 and candidates through yeast two-hybrid analysis

The growth of the yeast strains on $\beta$-galac-tosidase assay (+Leu, X-gal) media. ADG1 and candidates were used as a Bait and a Prey, respectively (top) and vice vesa (bottom). Only vector construct was used as negative control. 


\section{Confirmation of interaction between ADG1 and candidates}

For further functional study of non plastidic ADG1, the interaction firstly was confirmed by yeast two hybrid. According to yeast two hybrid confirmation results, among seven candidates, fours showed positive interaction by $\beta$-galactosidase activity assay. Since ERF7 and
STOP1 were reported as transcription factor in Arabidopsis, and $\mathrm{Y} 2 \mathrm{H}$ results also indicated auto-activation activity compared to vector control (fig. 3). Moreover, ERF7 and STOP1 can grow even in the medium containing glucose, which indicates that they are false positive interaction (data not shown).
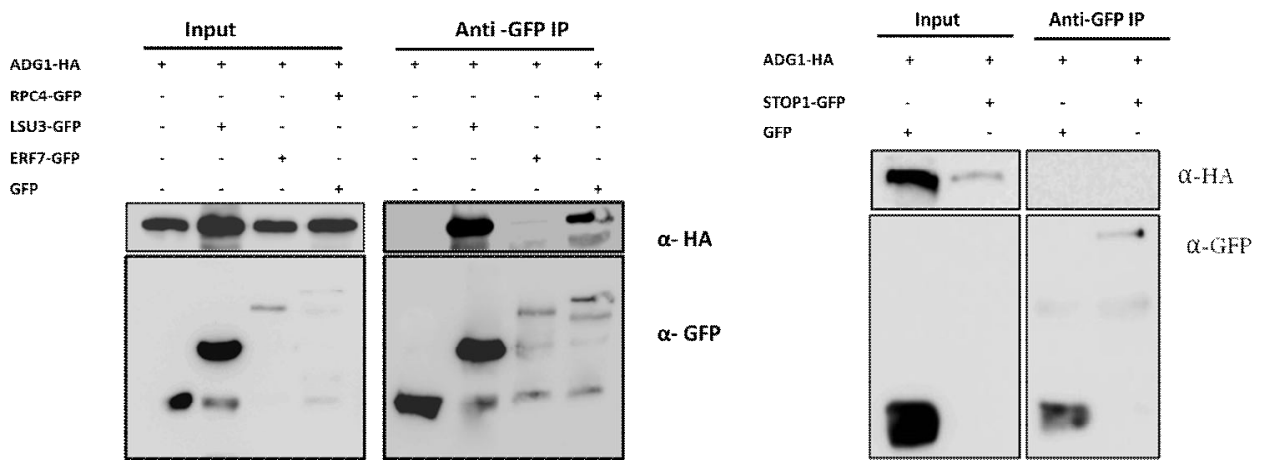

Figure 4. Co-immunoprecipitation of ADG1 with unconventional partners in vivo

GFP tagged candidates and HA tagged ADG1 co-expressed in the protoplasts are detected in the whole lysate (Input). Co-immunoprecipitation was performed with an agarose-conjugated anti-GFP Polyclonal antibody $(\alpha \mathrm{GFP})$. (Output were detected by immunoblot analysis with the anti-GFP ( $\alpha \mathrm{GFP})$ and anti-HA $(\alpha \mathrm{HA})$ antibodies. GFP construct was used as a negative control.

The interaction between ADG1 and RPC4 was confirmed from the positive clones by $\beta$ galactosidase activity assay in yeast system (figure 3). LSU3 shows lower $\beta$-galactosidase activity when it was used as a bait. However, no positive interaction from SEC14 and At3g19895 (unknown protein) could be observed (figure 3). Another protein (DNAJ heat shock N-terminal domain-containing protein (AT2G25560), no clone was successful. Genevestigator indicated that this protein expressed at extremely low level in Arabidopsis development.

To validate the $\mathrm{Y} 2 \mathrm{H}$ data further, in vivo coimmunoprecipitation assay was performed, haemagglutinin (HA)-tagged ADG1 was pulled down by GFP antibody in extracts of transfected protoplasts by GFP-tagged interacting candidates. GFP- fused candidates and HAfused ADG1 co-expressed in the protoplasts are detected in the whole lysate (Input). Coimmunoprecipitation was performed with an agarose-conjugated anti-GFP Polyclonal antibody $(\alpha \mathrm{GFP})$. Candidate-GFP and ADG1-
HA in the pellet fraction (Output) were detected by immunoblot analysis with the anti-GFP $(\alpha \mathrm{GFP})$ and anti-HA ( $\alpha \mathrm{HA})$ antibodies. GFP construct was used as a negative control. Figure 4 shows that ADG1-HA was detected in the proteins precipitated by anti-GFP from protoplasts co-transfected with both RPC4-GFP and ADG1-HA. The results demonstrated that RPC4 and ADG1 could be coimmunoprecipitated. LSU3 also showed strong interaction with ADG1 through Co-IP assay. However, the interaction between ERF7 and ADG1 shows minor compared to LSU3 interaction and no positive interaction could be seen from STOP1-GFP (fig. 4). Control experiments show that there is no protein coimmunoprecipitated with only GFP.

\section{CONCLUSION}

Applying yeast two hybrid screens, we have identified several putative unconventional partners of the ADP-glucose pyrophosphorylase small subunit (ADG1) in the nucleus of 
Pham Ngoc Vinh, Hong Gil Nam, Nguyen Huy Hoang

Arabidopsis. For further study function of non plastidic ADG1, the interaction was confirmed by yeast two hybrid and coimmunoprecipitation assays. Surprisingly, ADG1 was found to interact with RNA polymerase III subunit (RPC4) and Response to Low Sulfur protein (LSU3). RPC4 encoded for small subunit in the RNA polymerase III complex, which is essential for transcription of genes encoding short untranslated RNAs such as transfer RNAs (tRNAs) and 5S ribosomal RNA (rRNA). The function of RPC4 and LSU3 are still unknown in Arabidopsis. The subcellular localization of interacting candidates was also analyzed using laser scanning microscopy. The findings of ADG1 interacting proteins support a model in which conserved metabolic enzymes may perform previously unrecognized nuclear functions.

\section{REFERENCES}

1. Cho Y. H., Yoo S. D., Sheen J., 2006. Regulatory functions of nuclear hexokinasel complex in glucose signaling. Cell, 127(3): 579-589.

2. Crevillen P., Ventriglia T., Pinto F., Orea A., Merida A., Romero J. M., 2005. Differential pattern of expression and sugar regulation of Arabidopsis thaliana ADPglucose pyrophosphorylase-encoding genes. The Journal of Biological Chemistry, 280: 8143-8149.

3. Hong S. H., Kim H. J., Ryu J. S., Choi H., Jeong S., Shin J., Choi G., Nam H. G., 2008. CRY1 inhibits COP1-mediated degradation of BIT1, a MYB transcription factor, to activate blue light-dependent gene expression in Arabidopsis. The Plant journal: for cell and molecular biology 55, 361-371.

4. Jeffery C. J., 1999. Moonlighting proteins. Talking Point. TIBS 24.

5. Jong Sang Ryu J.-I. K., Tim Kunkel., 2005. Phytochrome-Specific Type 5 Phosphatase Controls Light Signal Flux by Enhancing Phytochrome Stability and Affinity for a Signal Transducer. Cell, 120: 395-406.

6. Lin T. P., Caspar T., Somerville C., Preiss J., 1988. Isolation and Characterization of a
Starchless Mutant of Arabidopsis thaliana (L.) Heynh Lacking ADP glucose Pyrophosphorylase Activity. Plant physiology, 86: 1131-1135.

7. Moore B., 2004. Bifunctional and moonlighting enzymes: lighting the way to regulatory control. Trends Plant Sci, 9(5): 221-228.

8. Moon H., Lee B., Choi G., Shin D., Prasad D. T., Lee O., Kwak S. S., Kim D. H., Nam J., Bahk J., 2003. NDP kinase 2 interacts with two oxidative stress-activated MAPKs to regulate cellular redox state and enhances multiple stress tolerance in transgenic plants. Proceedings of the National Academy of Sciences of the United States of America, 100: 358-363.

9. Moore B., Zhou L., Rolland F., Hall Q., Cheng W. H., Liu Y. X., Hwang I., Jones T., Sheen J., 2003. Role of the Arabidopsis glucose sensor HXK1 in nutrient, light, and hormonal signaling. Science, 300: 332-336.

10. Crevillen P., Ballicora M. A., Merida A., Preiss J., Romero J. M., 2003. The different large subunit isoforms of Arabidopsis thaliana ADP-glucose pyrophosphorylase confer distinct kinetic and regulatory properties to the heterotetrameric enzyme. The Journal of Biological Chemistry, 278: 28508-28515.

11. Reinhold H., Soyk S., Simkova K., Hostettler C., Marafino J., Mainiero S., Vaughan C. K., Monroe J. D., Zeeman S. C., 2011. Beta-amylase-like proteins function as transcription factors in Arabidopsis, controlling shoot growth and development. The Plant cell 23, 1391-1403.

12. Shue-Mei Wang W.-1. L., 1998. Characterization of ADG1, an Arabidopsis locus encoding for ADPGpyrophosphorylase small subunit, demonstrates that the presense of the small sununit is required for large subunit stability. The Plant Journal, 13(1): 63-70.

13. Tiziana Ventriglia M. L. K. M., 2008. Two Arabidopsis ADP-Glucose Pyrophosphorylase Large Subunits (APL1 and APL2) Are Catalytic1. Plant Physiology, 148: 65-76. 
14. Tsai H. L., Lue W. L., Lu K. J., Hsieh M. H., Wang S. M., Chen, J., 2009. Starch synthesis in Arabidopsis is achieved by spatial cotranscription of core starch metabolism genes. Plant Physiology, 151: 1582-1595.

15. Zeeman S. C., Smith S. M., Smith A. M., 2007. The diurnal metabolism of leaf starch. Biochemical Journal, 401: 13-28.

16. Ventriglia T., Kuhn M. L., Ruiz M. T.,
Ribeiro-Pedro M., Valverde F., Ballicora M. A., Preiss J., Romero J. M., 2008. Two Arabidopsis ADP-glucose pyrophosphorylase large subunits (APL1 and APL2) are catalytic. Plant Physiology, 148: 65-76.

17. Yoo S. D., Cho Y. H., Sheen J., 2007. Arabidopsis mesophyll protoplasts: a versatile cell system for transient gene expression analysis. Nature Protocols, 2: $1565-1572$.

\title{
PHÂN LẠP CÁC PROTEIN TƯƠNG TÁC VỚI ADP-GLUCOSE PYROPHOSPHORYLASE NĂM NGOÀI VÙNG LỤC LẠP Ở Arabidopsis thaliana
}

\author{
Phạm Ngọc Vinh ${ }^{1}$, Hong Gil Nam ${ }^{1}$, Nguyễn Huy Hoàng ${ }^{2}$ \\ ${ }^{1}$ Đại học Khoa học và Công nghệ Pohang (POSTECH) \\ ${ }^{2}$ Viện Nghiên cứu Hệ gen, Viện Hàn lâm KH\&CN Việt Nam
}

\section{TÓM TÁT}

Trước đây, ADP-glucose pyrophosphorylase (ATP: alpha-glucose-1-phosphate adenylyl transferase, ADGase) đã được nghiên cứu rât nhiều như một enzyme quan trọng trong quá trình sinh tổng hợp tinh bột ở thực vật. Tuy nhiên, tiểu phần nhỏ của ADP-glucose pyrophosphorylase (APS1 hay ADG1) được tìm thấy không chỉ ở trong lục lạp mà còn ở các vùng khác trong tế bào, đặc biệt một phần nhỏ trong nhân. Do đó, để nghiên cứu vai trò cơ chế mới của $\mathrm{ADG1}$ trong các cơ quan này, phương pháp sàng lọc lai nấm men đã được sử dụng để tìm ra các protein tương tác với $\mathrm{ADG} 1$ trong tế bào. Phương pháp lai nấm men và đồng kết tủa miễn dịch (Co-immunoprecipiation) đã được sử dụng để kiểm tra mối tương tác giữa $\mathrm{ADG}$ 1 và các protein tìm được qua sàng lọc lai nấm men. Ngoài ra, vị trí phân bố của các protein này đã được kiểm tra sử dụng protein phát huỳnh quang GFP quan sát dưới kính hiển vi quét laser. Kết quả cho thấy, RNA polymerase tiểu đơn vị nhỏ RPC4 và protein đáp ứng với môi trường sulfur thấp (LSU3), có khả năng liên kết với ADG1 trong tế bào. Việc tìm ra các protein có khả năng tương tác với ADG1 trong tế bào đã gợi ra một chức năng mới của $\mathrm{ADG} 1$ protein, có khả năng đóng vai trò cầu nối giữa môi trường bên ngoài với trao đổi chất tế bào và những tín hiệu bên trong tế bào để điều hòa quá trình sinh trưởng và phát triển ở thực vật.

Tù khóa: Điều hòa sinh trưởng, tổng hợp tinh bột, tương tác protein.

Ngày nhận bài:12-2-2014 